\title{
The Dutch Great Stink: The End of the Cesspit Era in the Pre-Industrial Towns of Leiden and Haarlem
}

\author{
RoOs van OOSTEN \\ Faculty of Archaeology, University of Leiden, Leiden, The Netherlands
}

In the nineteenth century, the continuous discharge of sewage from millions of Londoners into the River Thames caused a notorious, unbearable stench during the summer, which reached a climax in 1858 and became known as The Great Stink. In this article it is argued that such a 'Great Stink' also occurred in the booming and heavily populated pre-industrial town of Leiden, because cesspits were being replaced by serwers draining directly into canals. Flawed as cesspits may have been, the new, hygienic sewer infrastructure meant the advent of unsanitary conditions normally only associated with the era of the Industrial Revolution. How and why the cesspit was killed off is explained by comparing Leiden with the seventeenth-century boom town of Haarlem, where cesspits remarkably survived the 'Golden Age' of the seventeenth century. Using the stakeholder model it becomes clear that the shift in hygienic infrastructure was not the outcome of a single stakeholder calling the shots but was the result of interactions between tenants, housing developers, local government, and textile entrepreneurs (in the case of Leiden), or brewers (in Haarlem).

Keywords: Early Modern era, seventeenth century, Holland, sanitation, hygienic infrastructure, cesspits, stakeholder model, Great Stink, body social, urban archaeology

\section{INTRODUCTION}

How human excrement was processed in the industrial period has been remarkably well researched by historians. ${ }^{1}$ Van der Woud in Koninkrijk vol sloppen ( $A$ Kingdom of Urban Slums, 2010) makes it crystal clear that Dutch towns in the nineteenth century were overcrowded, had poor public hygiene, and tolerated filth everywhere. The water in urban canals was

\footnotetext{
${ }^{1}$ This article is an adaptation of part of my $\mathrm{PhD}$ dissertation written in Dutch (defended in 2014; commercial edition Van Oosten, 2015). For this article, I selected two of the seven towns studied in my dissertation for application of the stakeholder model.
}

polluted and contaminated, with privies and latrines draining directly into them. Furthermore, the waste from the burgeoning factories was also discharged into the canals. As a result, many towns experienced outbreaks of epidemics, not only of traditional diseases such as smallpox and measles but also, from1832, of waterborne Asiatic cholera (Houwaart, 1991: 98; Meijer, 2005). In several towns doctors compiled distribution maps to record deaths from cholera (see Meijer, 2005 for Leiden; see Johnson, 2006 for London). Although the cause of cholera was not properly understood, such distribution maps made the strong correlation between 
living in urban slums and dying of cholera obvious. Progressive doctors in the Netherlands who followed the so-called Hygienist Movement (1840-1890) implored local governments to intervene and institute a better sanitary infrastructure. Local authorities were slow to respond, but after decades of lobbying the public sanitary infrastructure was eventually improved. Contaminated canals were filled in one after another, and in the 1870s more than thirty towns instituted systems for collecting human waste involving portable toilets or commodes and pail closets (Van Zon, 1986: 85), known in the Netherlands as tonnenstelsel or fosses mobiles (pail system or Rochdale system). In this new system, slop barrels were emptied weekly by a newly established municipal service.

In the mid-nineteenth century, human excrement simply drained into the canals. Reading Van der Woud's Koninkrijk vol sloppen as a historian, I took this fact for granted; as an archaeologist, however, this struck me as somewhat surprising, for in Dutch urban excavations, a cesspit can be found in nearly every plot. $^{2}$ There are various styles and types of cesspit, but in towns like Haarlem and Leiden, more than eighty per cent of the archaeologically recorded cesspits are round, brick-built, and covered with a brick-built dome (Figure 1; see also Van Oosten, 2015). The consistent type of construction suggests that cesspits were built by specialist tradesmen at the time the adjacent buildings were being erected. My first

\footnotetext{
${ }^{2}$ For the record, like the Netherlands, in British archaeology 'many excavators tend to describe all unlined pits - containing either privy waste or general domestic waste - as 'rubbish pits' (Evans, 2010: 269-70) rather than as cesspits. Evans (2010: 267) rightly pledges to give thought to what we mean by such terms. In English articles with a historical focus the terms 'cesspool' and 'latrine' are more common (Sabine, 1934). In this article, I use the term 'cesspit' for any lined or unlined pit in which human waste was collected and that served as a privy. Here cesspit has a functional, not a morphological, meaning.
}

question will therefore be: when did the sanitation system shift from cesspits to drains and canals?

Although it is obvious that in the nineteenth century canals clogged with human faeces served neither the urban community nor the common good, the shift from drains and canals to the tonnenstelsel system did not happen overnight. It is also evident that in the nineteenth century this transition in hygienic infrastructure reflected a social confrontation between different stakeholders, the principal stakeholders being the local government, the hygienists, and the industrialists. Industrialists, and to some extent local government, regarded the draining of industrial waste into the canals — the largest source of pollution - as a precondition for the continued presence of factories in their towns; without these factories, the threat of unemployment loomed over the townsfolk. As long as local authorities made no effort to curtail this pollution, private individuals had no qualms about dumping their waste or draining their privies into the canals. The social 'battle' between the stakeholders is illustrated in Figure 2.

The second question addressed here consists of identifying the stakeholders involved in this pre-industrial transition, in other words: who killed off the cesspit and for what reason? ${ }^{3}$

In order to discover when, why, and by whom sewers were installed, we need to trace the history of sanitation management in Dutch towns. We shall focus on Haarlem and Leiden, two of the many towns that experienced an economic boom

\footnotetext{
${ }^{3}$ The metaphor of killing something inanimate is inspired by Latour's 1996 book Aramis, or the Love of Technology. Aramis was not a person but a very advanced public transport system in Paris. Although millions of French francs were spent on the eighteen-year project, it never went beyond the test stage. The main question of the book is who killed Aramis? To this end Latour identifies many different actors or stakeholders.
} 


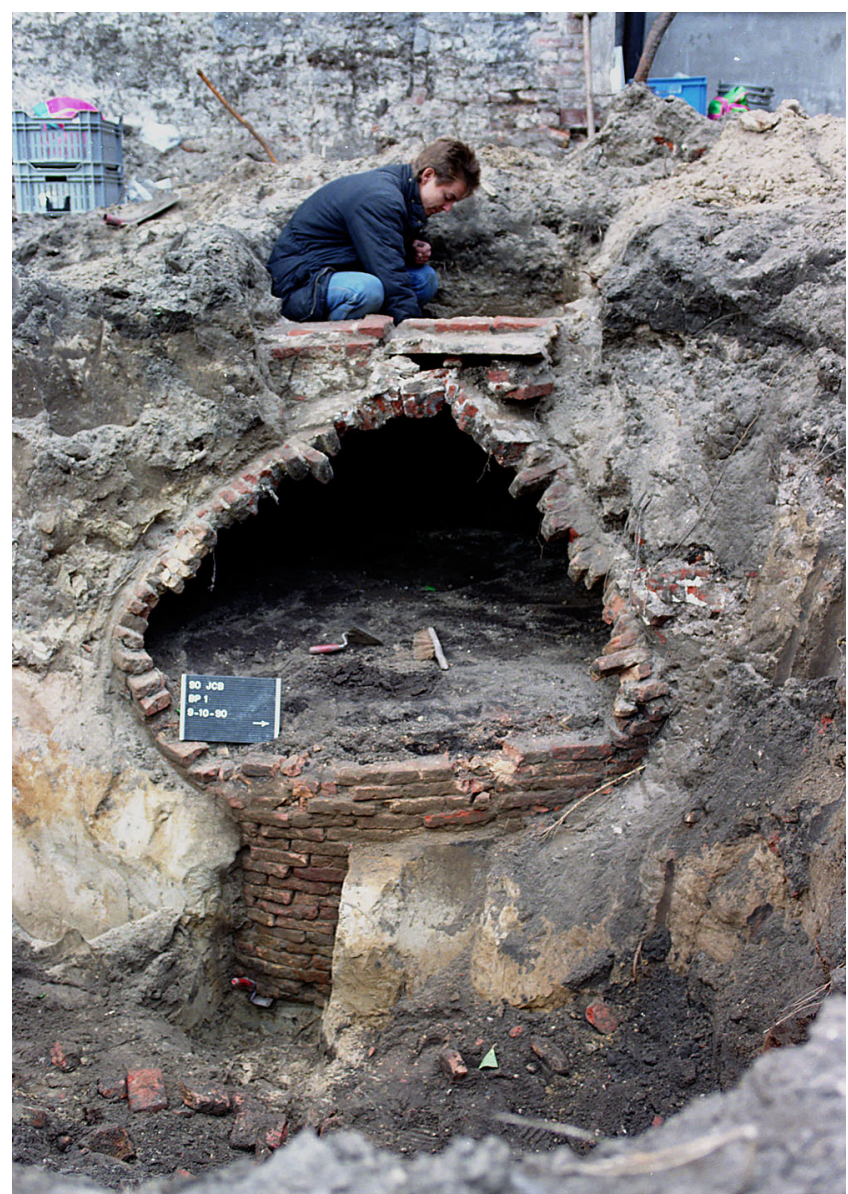

Figure 1. Haarlem: a round, domed, brick-built cesspit. By permission of the Municipal Archaeological Service of Haarlem.

in seventeenth-century Holland. Haarlem and Leiden had a similar socio-economic history in the pre-industrial period, but, as will be demonstrated, dealt differently with what in those days was referred to as 'the matter of the faeces'.

\section{A Socio-Economic Outline of HaARlem and LeIDEN}

Both Haarlem and Leiden were water-rich towns that grew from small, semi-rural,

4، de kwestie der fecaliën' walled settlements in the thirteenth and fourteenth centuries into towns where the rural lifestyle had more or less disappeared and inhabitants increasingly earned their livelihood in urban occupations [compare Figure 6(a) and (b)]. Both Leiden and Haarlem had important wool-based textile industries, but in Haarlem the textile industry was of secondary importance, outstripped by beer production (Ampzing, 1628: 337).

The historian Hanno Brand (2008: 103) describes Leiden as a typical preindustrial town that was organized on a capitalist footing as early as $\mathrm{AD} 1500$. 


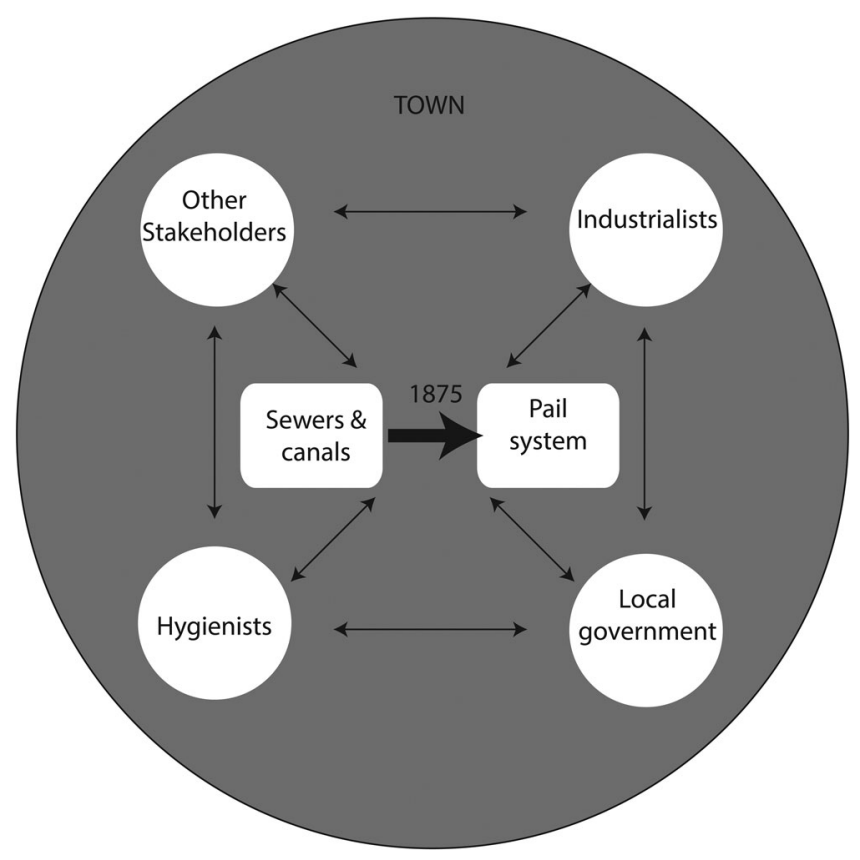

Figure 2. The Stakeholder model applied for the shift from sewers/canals to the pail system c. 1875. The arrows indicate the relationships between stakeholders and their shared vested interest in whichever system was used.

Large enterprises distributed raw materials and part-finished products to the homes of spinners, weavers, and tuckers. This system of outsourcing was characterized by an extensive division of labour (Kaptein, 1998: 249; Posthumus, 1908: 269-71, 404; 1910: xv-xvii). By 1500 wealth inequality in Leiden (and to a lesser degree in Haarlem) was considerable by international standards (Van Zanden, 1998: 38). The close collaboration between the richest textile entrepreneurs (drapers) and the city council in implementing a repressive pay policy was typical for Leiden at that time; it meant that fullers, tuckers, dyers, and weavers had an extremely low earning potential in contrast to the wealthy textile barons at the top (Brand, 2008: 100-03). The Armenrapport (Poverty Report), written in 1577 by Leiden's talented stadssecretaris (town clerk) Jan van Hout (1542-1609), reveals that the extreme poverty in Leiden was caused by textile entrepreneurs who were solely motivated by becoming 'rich, powerful, and great and never cared about paying their craftworkers a fair wage but forced their workers into a position of slavery' (Kaptein, 1998: 150; see Van Maanen, 2010 for the background to the Poverty Report). Although wealth inequality was considerable in Haarlem as well, such marked early proletarization appears to have been unique to Leiden (Kaptein, 1998: 150, 167).

At the time of the publication of the Armenrapport in 1577, Leiden numbered around 12,000 inhabitants, 4000 fewer than before the recent Spanish siege (1573-1574). The decline in population caused by the siege was more than compensated for by the thousands of political refugees from the southern Netherlands whom Leiden welcomed from the 1580 s 
onwards (De Vries et al., 2003: 93-95; Lucassen, 2002a, 2002b: 27). At its zenith in the 1660 s, Leiden reached a population of 62,000. The urban population of Haarlem also grew explosively after its own Spanish siege of 1572-1573 (see Figure 3 for population trends in Leiden and Haarlem). In the seventeenth century, both Leiden and Haarlem were among the five largest towns in the Netherlands.

The unprecedented, large, and rapid demographic rise affected everyday life for Leiden's inhabitants, most notably in the continuous shortage of housing (Noordam, 2003: 43-45; Van Maanen, 2009: 54-57; Van Oerle, 1975: 430-34). Dwellings were being constructed - in Leiden the housing stock rose by 182 per cent within twenty-five years (1581-1606) - but the demand for cheap housing continued to outpace supply (Daelemans, 1975: 187). Many families lived in shared accommodation (Posthumus, 1939: 161). The few available records of rental rates for houses in Leiden suggest that between 1581 and 1619 average rents rose by 240 per cent (Posthumus, 1939: 208). This was not exceptional: in Amsterdam house rents tripled between 1580 and 1595 (Lesger, 1986: 38-48). Such a situation reflects the general trend in Holland, where average rents show 'a very strong increase between the 1560s and 1630s' (Van Zanden, n.d.). Despite these shortcomings, the influx of skilled workers contributed to the well-documented explosive economic growth of Holland. However, in the so-called Golden Age of the seventeenth century, wealth was concentrated in the hands of a small elite, and wealth inequality increased (Van Zanden, 1998: 32, 36).

After the economic miracle (Wirtschaftswunder), Holland experienced a period of stagnation in the second half of the eighteenth century, and the relatively labour-intensive sectors, like the textile industry, were affected first (Van Zanden, 1998: 53). To make things worse, the same period saw sharp rises in food prices. For the growing class of paupers - the vast majority of a town's residents - it was quite a challenge even to feed themselves from week to week (De Vries, 1995;

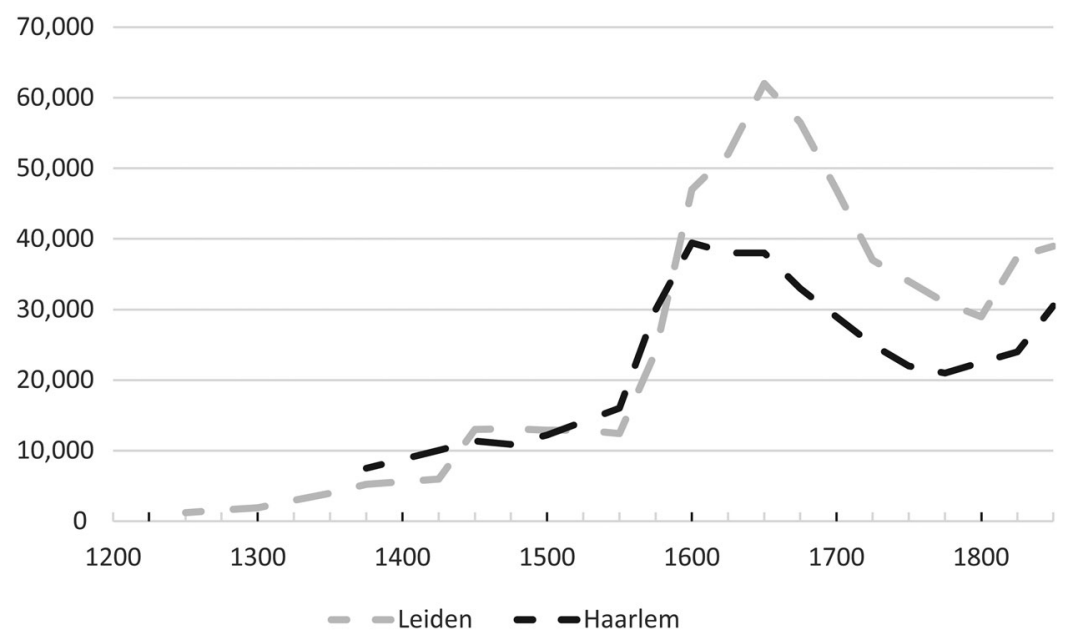

Figure 3. Population trends in Leiden and Haarlem, thirteenth-nineteenth century. For the data I refer to the tables in Van Oosten (2015, appendices 4.1 and 4.2). The broken lines indicate that this graph is based on estimates made by historical demographers; exact figures are rarely available. 
Pot, 1994: 341). Leiden's poor had to deal with an artificially high, fixed bread price; the bakers enjoyed significantly greater profit margins than bakers in other towns. It is significant that the town council explicitly approved this policy and collaborated with the bakers (Van Zanden, 1991: 134). By 1800 Haarlem and Leiden had become impoverished towns, where the quality of life was to decline further throughout the nineteenth century as a result of waste dumping, decayed housing, dilapidation, and 'slumlording.'

\section{Archaeological Dataset: Three Phases in Urban Development and in Dealing with Human Excrement}

In the thirteenth century, both Leiden and Haarlem were small towns where many residents led a rural life intra muros. How human excrement was managed in such agrarian settings is not clear: it is archaeologically invisible $[$ for an artist's impression of this agrarian phase, see Figure 6(a)]. The waste was definitely not collected in cesspits; perhaps it was discharged into ditches or used as fertiliser in combination with animal manure. Excavation plans indicate that as soon as regular plots for house construction were established in the fourteenth century [see Figure 6(b)], cesspits started to appear in large numbers. Cesspits proliferated at the same time as brick-built houses began to emerge. The two developments did not converge arbitrarily, but were the result of close municipal supervision of the housing industry and an overall increase in the degree of professionalization. Both were closely related to a rising urban population density and the concomitant process of de-agriculturalization, that is, the disappearance of rural forms of livelihood from the confines of towns.
In order to better understand the chronological distribution of cesspits for the town as a settlement, a dataset of archaeologically recorded cesspits was compiled by going through the forty-one issues of Haarlems Bodemonderzoek (a journal devoted to archaeology in Haarlem), the twenty-nine issues of Bodemonderzoek Leiden (devoted to archaeology in Leiden), and additional archaeological reports. For Haarlem, more detailed evidence was gleaned from the field notes and field drawings of earlier archaeologists, stored in the archives of the Municipal Archaeological Service. This produced a list of 104 cesspits from Leiden and 298 cesspits from Haarlem, all with an ascribed use-life.

For a cesspit to be included in this list, its date of construction and abandonment needed to be established. Structures without any ascribed date were omitted from the list. Most pits had only been assigned a date in the field, which was recorded in the field notes (a technique known as spot-dating); at other times they were assigned after a quick scan of the finds during post-excavation analysis. Provisional datings tend to be typified by wide margins (e.g. seventeenth/eighteenth century) and rounded-off dates (e.g. $1600-1800$ rather than $1625-1775)$. It is often unclear whether these wide ranges reflect the actual lifespan of the cesspit or caution on the part of the archaeologists.

The problem of dating cesspits is more immediate for the end-of-use date than for the starting date. When in use, most cesspits were cleared out on a regular basis. In the event of partial emptying, as was often the case, the bottommost layer would remain untouched, making it possible to deduce the starting date of a cesspit's lifespan fairly accurately. Pinpointing a closing date proves more problematic, as the freshest, topmost layers were likely to have been removed shortly 
after a cesspit was decommissioned in an effort to reduce any residual odours. Consequently, the upper layers containing the freshest finds may no longer be archaeologically visible and the lifespan assigned to the cesspit will be shorter than its actual use. That the lifespan attributed to individual pits comes with a margin of uncertainty is a limitation of the dataset.

In order to transform the list of cesspits and their use-life into a cesspit trend line which could be compared with demographic trends and population density, I created a time-line of quarter centuries with a score table. For example, a cesspit might have been in use from 1600 to 1675 , the first three quarters of the seventeenth century, and thus these three quarters would each score one cesspit in the time-line. Determining all the cesspit scores per quarter century in this way and adding up all the scores generated the number of archaeologically documented active cesspits per quarter century. Connecting these total scores produced the cesspit trend lines shown in Figures 4 and 5. As the number of archaeologically documented active cesspits is not an exact figure but an estimate, the trend lines, like the demographic trends, are not presented as a solid line. In Figures 4 and 5, both the demographic trend and the cesspit trend are illustrated: the $x$ axis represents the time-line in quarter centuries, the $y$ axis on the left shows the number of inhabitants, and the $y$ axis on the right the number of cesspits.

The cesspit trend line can be compared with the demographic trend and the trend in population density. The expectation is that a growing population will go hand in hand with a rise in cesspit numbers. (As both trend lines are based on estimates, we shall focus only on the very obvious high peak of the seventeenth century.) As Figure 4 illustrates, the case of Haarlem seems to support this hypothesis. The rise in population numbers is associated with a rising number of cesspits. By contrast, Figure 5 shows that in Leiden the opposite occurred: whereas the population density rose in the seventeenth century, the number of cesspits dropped dramatically. In Leiden, the cesspit era ended around AD 1600.

The archaeological evidence from Leiden clearly shows that shortly before 1600 cesspits were replaced by brick-built drains or sewers draining into the canals

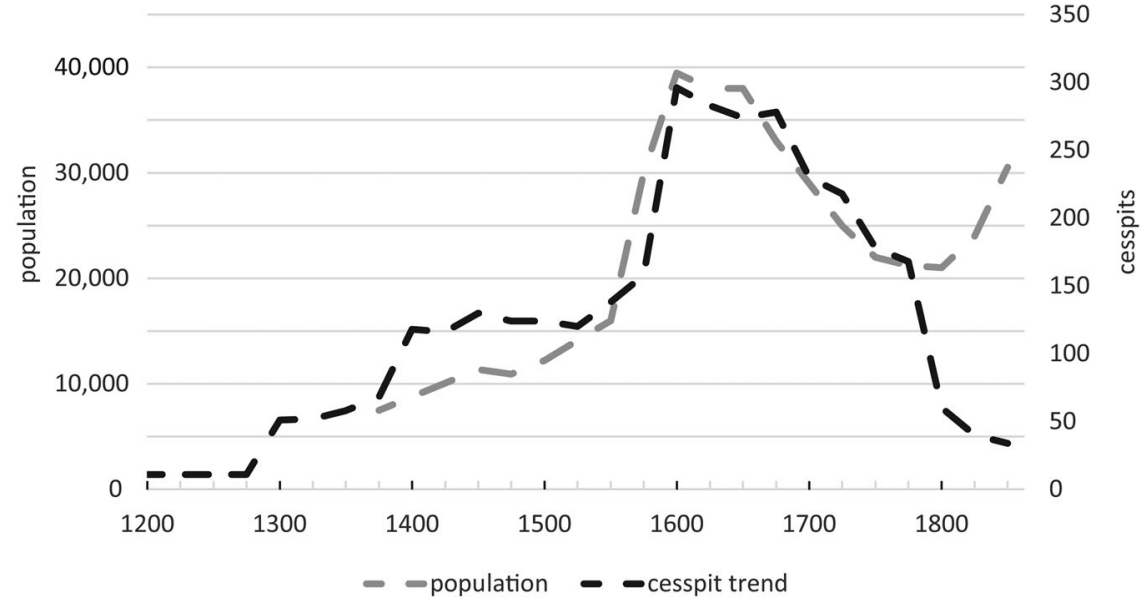

Figure 4. Haarlem, trends in population and active cesspits. 


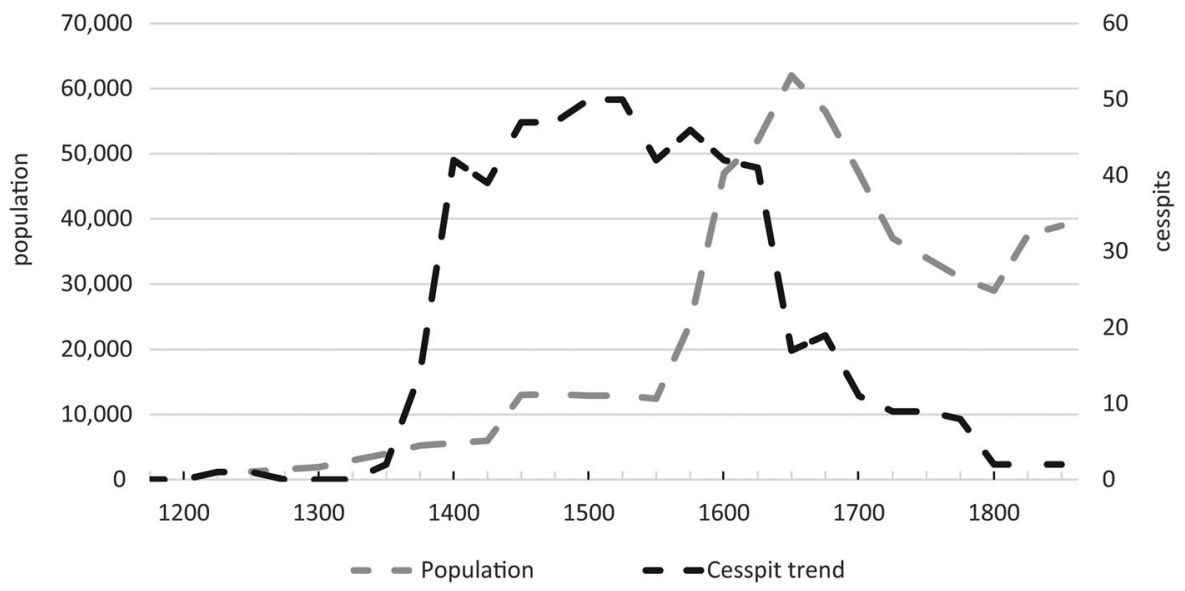

Figure 5. Leiden, trends in population and active cesspits.

(Figure 7). More than twenty-six have been uncovered in the city centre. These conduits ran from the privy in the back yard, below the house, in a straight or zigzag line down the street and into the canal (Figure 6c). It is difficult to date these drains exactly, as no artefacts have been retrieved from them. More closely datable are drains referred to in historical sources (e.g. a drain mentioned in technical specifications in a 1592 design brief; Lunsingh Scheurleer et al., 1990: 568) and drains that turn up during building archaeology research (e.g. drains dated 1630 and 1660; see Van Oosten, 2015: appendix 4.8 for a list of the drains revealed). Of greater significance than these interesting but isolated references is documentary evidence that suggests that a primitive brick-built sewer system was constructed as part of the town expansion of 1659 (Taverne, 1978: 234). Contractors built the general collector drain below the public streets, while developers had to ensure at a later date that the private sewers were properly connected [Erfgoed Leiden en Omstreken (Heritage of Leiden and Environs), hereafter ELO, SA II, inv. no. 1393, f. 395]. Remarkably few excavations have taken place in the town extension of 1669; only in the past two years have archaeological excavations begun to record this sewerage infrastructure (Meijer \& Van den Bos, 2014).

Both Leiden and Haarlem, as reflected in their archaeology, experienced a rise in cesspit numbers during the late mediaeval period. After this cesspit era, cesspits were replaced by sewers. Leiden saw a sharp decrease in active cesspits in the seventeenth century; in Haarlem the accelerated decrease in active cesspits did not occur until the nineteenth century (Figure 4). In the following section we shall examine these two specific shifts in the light of historical evidence.

\section{Historical Data on Sanitation Management}

There are few historical records concerning sanitation management available, but two ordinances are so specific that they allow us to identify three stakeholders: one ordinance was passed in Leiden in 1463 and the other in Haarlem in 1540. In addition to Leiden and Haarlem, at least 


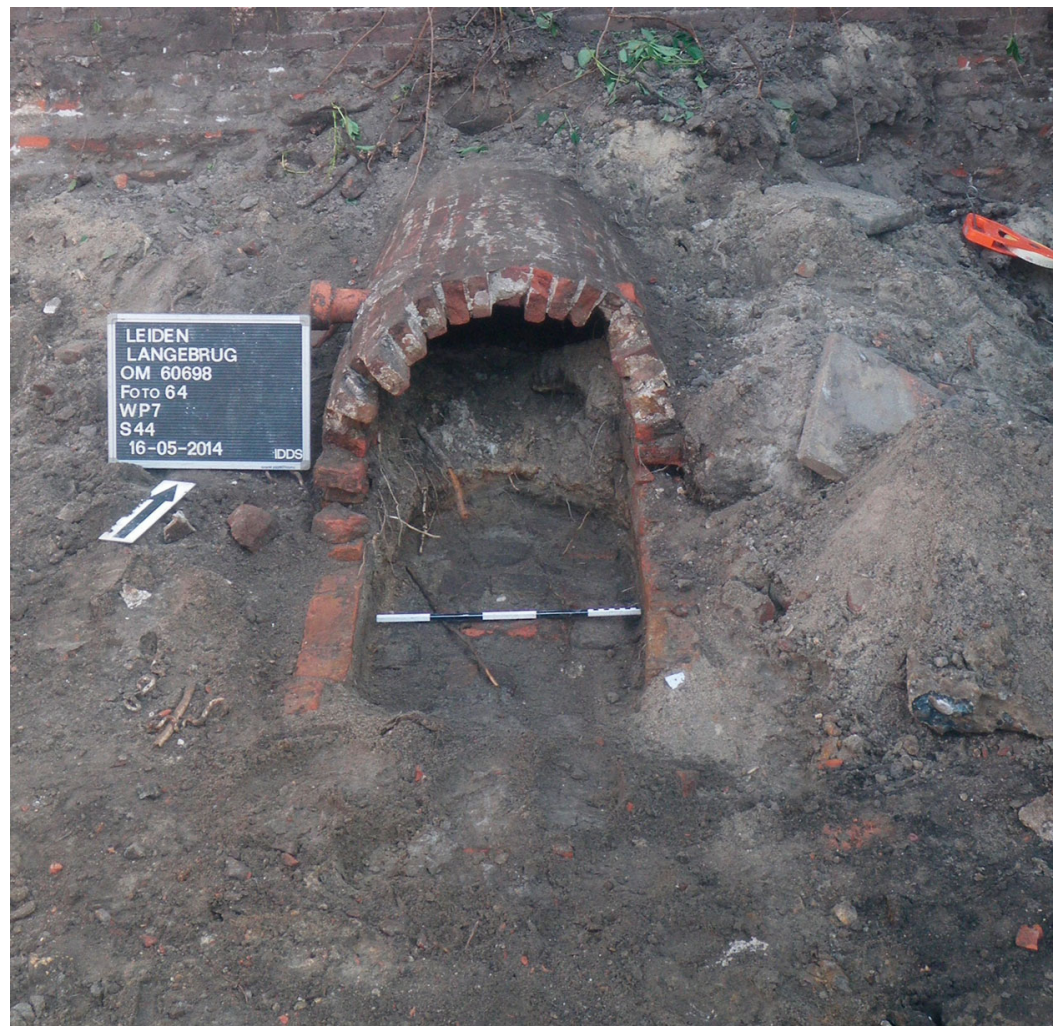

Figure 6. A brick-built sewer in Leiden, Langebrug excavation site. By permission of Bart Corver, IDDS archaeologists (Noordwijk).

eight other towns in the Netherlands passed similar cesspit by-laws in the late mediaeval period, and in other parts of Europe comparable regulations on cesspits were incorporated into local legislation at the same time (Jørgensen, 2006: 6).

In 1463 the city council of Leiden promulgated a by-law that stated that 'every house [including those] that are rented must have a privy at its disposal. ${ }^{5}$ The law did not require a cesspit to be built for every house, but only stated that every dwelling should have a cesspit nearby. Legally, several households could share a cesspit. However, the sharing of large

\footnotetext{
${ }^{5}$ Elc huys of camer, die te huyr gaen, een stille of pishuys ende heymelicheit te hebben'
}

cesspits, like those documented in Hull for instance (Evans, 2004: 65-66, fig. 8(c)) or Lübeck (Gläser, 2004: 191), does not seem to have been common practice in Leiden or Haarlem. The round cesspits in both Dutch towns were of modest diameter and hence of limited capacity, more suited to single- than to multiplehousehold use (Van Oosten, 2015: fig. 2.28). The law also stipulated that the privy should be a stand-alone facility, meaning that an overflow or sewer that drained into the nearest canal was prohibited.

The cesspit law in Leiden was remarkably detailed: the ordinance states that offenders had until 1 May (1464) to seal off any inappropriate drainage after which 
they would be fined. The historian Dick De Boer (1983: 91) assumes that the law acted as a catalyst for cesspit construction in Leiden. However, judging by Leiden's numerous cesspits dating to between 1375 and 1450 (Figure 5), constructing a cesspit rather than a conduit to the nearest canal must already have been common practice for every home at the time, regardless of its size or whether it was rented or owned. This ordinance thus did not embody a new policy or direction, it merely institutionalized or recorded a common practice and constituted an outright ban on sewers to the canals.

A similar by-law was promulgated in Haarlem, first in 1540 and five times in total between 1540 and 1557. The Haarlem text specifies that the cesspit should be constructed in a place where the privy can be easily accessed. The cesspit itself should be made of brick but a wooden barrel would also be allowed. Drainage into a canal was prohibited, and, as in Leiden, the ordinance explicitly stated that the rules applied equally to rental homes (Huizinga, 1911: 316, 321).

The 'cesspit law' passed in Leiden reveals that in the late mediaeval period there were three stakeholders, each with different interests when it came to sanitation management: the local government, tenants, and housing developers or landlords. Whenever municipal legislators spoke out in favour of this ordinance, all arguments referred to the public interest of having high-quality water in the town's canals and to its importance for the social and economic infrastructure. The accumulation of dirt and sludge in canals, which were the main transport routes, was considered harmful to the local economy. Moreover, the blocked waterways hampered the drawing of water from the canals for extinguishing fires (Hamaker, 1873: 148-49; Huizinga, 1911: 316). This was not solely a local concern: along with stench and contamination, the by-laws of other towns in north-western Europe also frequently mention 'traffic hindrance' as a reason for similar laws (Jørgensen, 2010b: 37). Apart from these practical considerations, draining human waste into the canals was also believed to harm the common good (Jørgensen, 2010a). Polluting and clogging the town's arteries (i.e. waterways) would threaten the urban body or body social (Rawcliffe, 2013). The emergence of cesspits and the policy of the city fathers in the water-rich towns of the Dutch coastal provinces can be regarded as material evidence of a utilitarian principle being applied. This principle of the needs of the many outweighing the needs of the few was expressed in the form of policies and statutes employing such terms as res publica and bonum commune communitatis (Stein et al., 2010).

Tenants make up the second stakeholder group; their interest was to have a good privy that contributed to their home comfort. In late mediaeval towns, tenants comprised about one-third of the population. Significantly, over the course of the seventeenth century, the proportion of owner-occupiers in Haarlem and Leiden dropped from two-thirds to about half. In 1606 the proportion of tenants in Leiden was forty-two per cent, and in Haarlem in 1628 it was fifty-four per cent (Figure 8).

Tenants were indeed a large group, but they did not have much of a voice. Any decision about installing an underground, brick-built cesspit was made by the developers and landlords, the third stakeholder group. I have grouped developers with landlords because they had similar interests in that they both rented out housing. As Soly (1977: 116-29) has shown for Antwerp, developers employed a strategy of renting out housing as a form of permanent income.

The cesspit law of 1463 reminded housing developers of their responsibilities. 

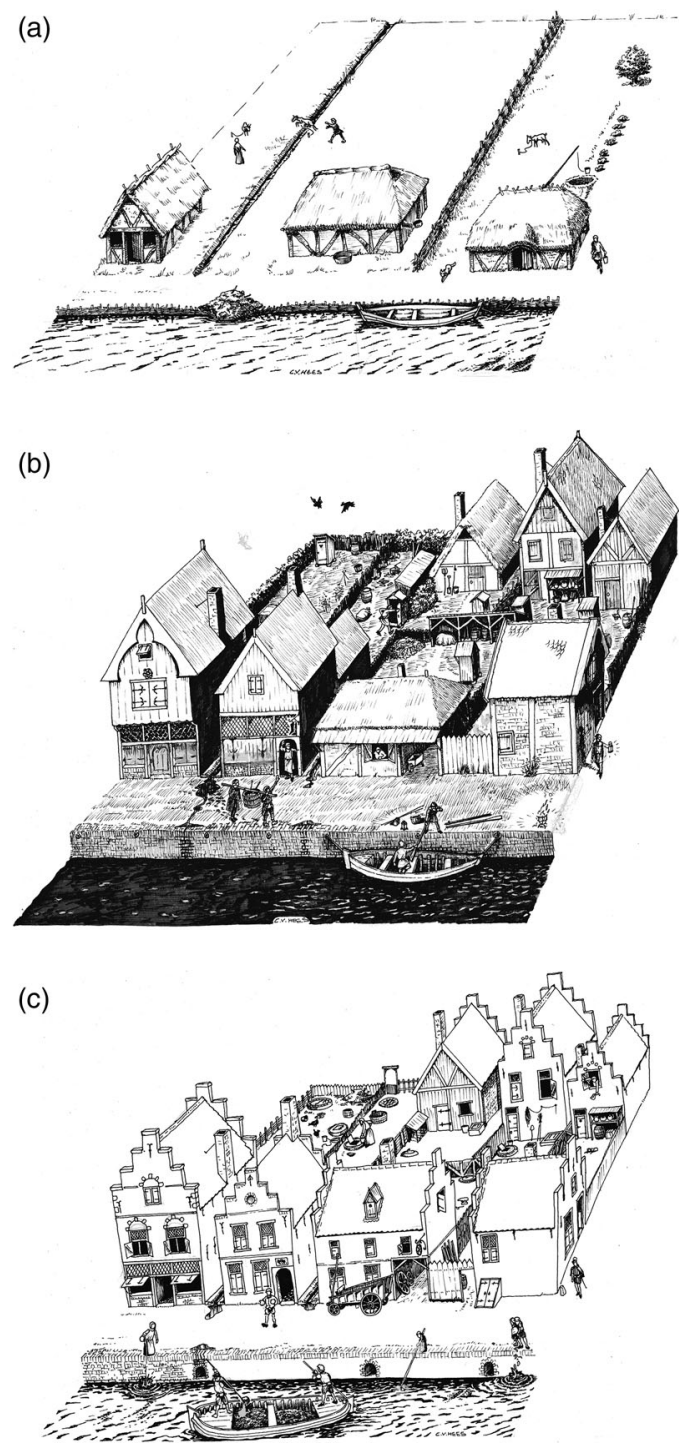

Figure 7. An artist's impression of three phases of urban development and human excrement management. Drawings by Carl van Hees (Leiden). (a) Haarlem or Leiden in the thirteenth century, a town with a rural character. In this phase, privies seem to be absent, i.e. there is no archaeological evidence of privies. A pile of dung is ready on the quayside/shore to be brought by barge to surrounding fields outside the town walls. (b) Haarlem or Leiden in the fifteenth century ('the cesspit era'), when the town was small: for most of the century it had fewer than 10,000 inhabitants and a low population density. Privies are located in the rear of the yard or near the house. Nightmen collect waste in tubs and carry it from the cesspit to their barge. The water in the canal is relatively clean and is used as household or drinking water; breweries also drew their water from the canals in this period. (c) Leiden in the seventeenth century, a large town with about 50,000 inhabitants and a high population density. Privies no longer drain into cesspits. Brick-built sewers that run from the privy in the backyard or in the house are now embedded in the stone quay and drain the waste straight into the canal. Town dwellers dump human waste into the canal. The result is a great stink. Barges are now used to dredge the canals regularly, but the water in the canals is no longer fit for consumption. Brewers start to bring fresh water by ship; gradually consumers start to construct shared or private water wells in their yards. 


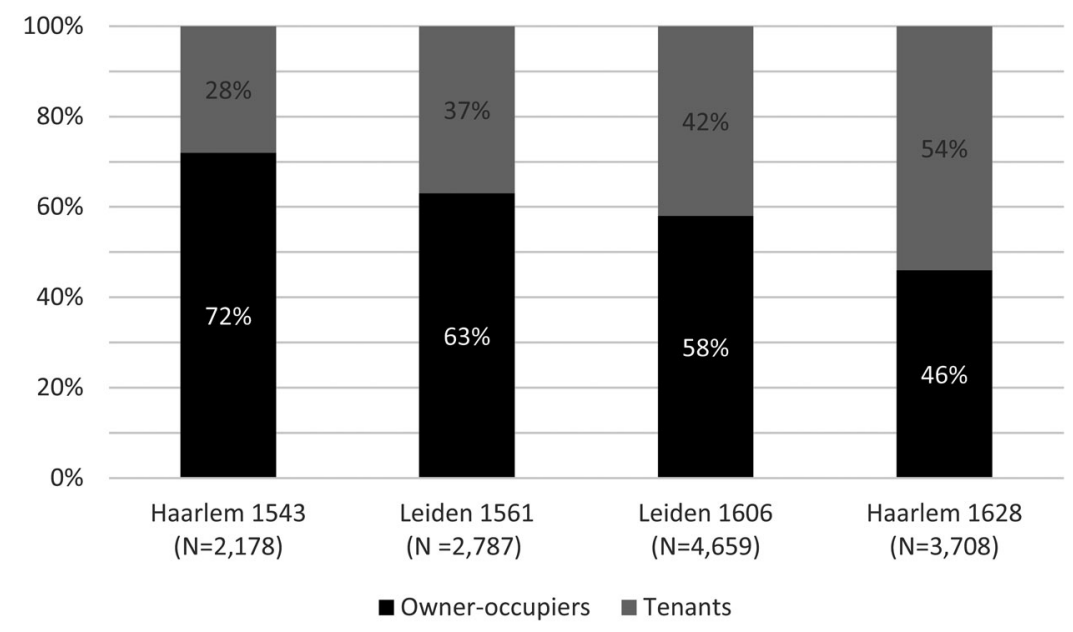

Figure 8. The proportion of tenants in Haarlem and Leiden in the sixteenth and seventeenth centuries. Sources: for Haarlem 1543: Boeschoten E Van Manen, 1983: 526; for Leiden 1561: Noordam, n.d.; for Leiden 1606: Posthumus, 1939: 160-61; for Haarlem 1628: Annema, 1984.

This was pertinent to the mid-fifteenth century when Leiden experienced a period of economic boom and increased house construction (De Boer, 1991: 40). Landlords were responsible for providing cesspits for all of their housing, regardless of the rental rate, and the ordinance stated that if landlords failed to fulfil their obligation, tenants should notify the city fathers. More specifically, the law stated that any tenant who moved after 1 May into a house that had a privy draining directly into a canal should report this within a month.

Landlords were not naturally inclined to build cesspits for their tenants; they preferred privies that drained into the canals. The by-laws do not explicitly state why they preferred this, but it is reasonable to assume that it was related to the cost of emptying cesspits. Few rental contracts have survived, but in the seventeenth century such contracts stated that landlords, in addition to the obligation of maintaining the roof and the walls, had to ensure that cesspits were regularly cleared out (Lesger, 1986: 24). Evidently, even as early as 1463 , landlords were trying to eschew this financial burden.

\section{Leiden: A Great STINK IN THE Seventeenth Century}

Leiden's cesspit ordinance raises the question of why such a change from cesspits to sewers was tolerated. Both the archaeological and historical evidence clearly show that the cesspit was killed off. It is telling that Leiden's 1538 statute book no longer incorporated the cesspit ordinance (Smit, 2001: 66). This means that the local government now approved a practice that had previously been forbidden.

It takes little to imagine the consequences of sewers discharging the excreta of 62,000 burghers into Leiden's largely stagnant canals. The causal relationship between sewage draining into the canals and increased pollution was not lost on contemporary observers. For example, the geodesist Jan Pietersz Dou (1572-1635), who had been commissioned to tackle the issue of the limited flow in Leiden's canals, wrote in 1633 that the fouling of the canals was primarily caused by the many sewers that were constructed throughout the town and drained into the canals $^{, 6}$ (ELO, SA II, inv. no. 5172, 
f. 134, artikel 23 dated 19 August 1633; also quoted by Taverne, 1978: 204). The effluent from "dirty industries" ${ }^{7}$ was only a secondary cause, according to Jan Pietersz Dou. Adam Thomasz Verduyn, writing in 1670 , also blamed the serious pollution on the sewers (Verduyn 1670a: 5). Furthermore, the pollution of canal water was so bad that live fish disappeared altogether (Verduyn 1670a: 12-13). For this reason he termed Leiden a "stinkholes that reeked like a 'common privy' (1670a: 1213). Without a doubt, Leiden was producing its own Great Stink. ${ }^{10}$ The canal pollution brought about by the replacement of Leiden's cesspits by sewers had reached 'industrial' proportions.

While the cause of the contamination was known, a solution was not within easy reach. In 1591 the town clerk Jan van Hout, mentioned above, had drawn up a 'water exchange' masterplan involving mills pumping the dirty water out of the canals (Van der Paauw, 1828: 115-26; for the original text, see ELO, SA II, inv. no. 15, Aflezingboek E, f. $1-$ f. 10 , dated 5 June 1591). Although this did help, closing the sewers would have been more effective. The latter measure was put forward by the municipal architect Arent van 's-Gravesande (1610-1662). However, in 1642 he appears to have realized that turning back the clock would be considered unreasonable, so instead he suggested that a sewerage charge be levied, the proceeds to be earmarked for improving water circulation in the town (ELO, SA II, inv. no. 5172, f. 203, dated 30 December 1642). Only a few of Van

\footnotetext{
${ }^{6}$ 'de menichte van de secreetgoten die allomme door de stadt in de wateren zijn geleidt'

7، vile neringen'

8'stinck-gat'

9'gemeen privaet'

${ }^{10}$ This term was used to describe the notorious, unbearable stench from the continuous discharge of waste from millions of Londoners into the Thames that polluted the air each summer and reached its climax in 1858.
}

's-Gravesande's measures were actually implemented. In 1684 the town's bonmeesters (district managers) were instructed to ensure that the mouths of the sewers were constructed below the water surface, even at its lowest summer level (ELO, SA II, inv. no. 192, f. 49, 29 July 1684; also quoted by Van der Paauw, 1828: 92). The result may have improved appearances, but it did nothing to improve the water quality.

\section{The Needs of the Happy Few}

Using a cesspit means that sooner or later the cesspit will fill up. ${ }^{11}$ As is well documented in cities such as London (Sabine, 1934: 316) and Antwerp (Poulussen, 1987: 40-41), at least in the Early Modern period, clearing out cesspits was the work of professional nightmen. It was very expensive, as it was a filthy, labourintensive job, carried out during the least sociable hours. In seventeenth-century Leiden and Haarlem, this public service was organized by private individuals; as a consequence, few written records have been preserved. However, some evidence has survived in the annual accounts of the boards of institutions such as orphanages and almshouses, which by way of investment rented out various dwellings. In Leiden, the board of Sint Agnietenhof, a complex of almshouses, recorded the nightmen charges in its annual accounts; in the supplements to the accounts the original receipts on the back of the nightmen's tickets - thirty-four handwritten tickets in total - were also kept (ELO, Sint Agnietenbegijnhof inv. no. 27A, Bijlagen bij de rekeningen). On these tickets the price of emptying a cesspit was

\footnotetext{
${ }^{11}$ Building a new cesspit was an option - e.g. at the Spaarne 102-104 site in Haarlem (Jacobs, 2003: 36, figs 2 and 43) that was sometimes preferred to emptying an old cesspit, completely or partially.
} 
recorded. On average it amounted to 5.50 guilders. In Haarlem, the accounts of the Mennonite Orphanage reveal that the cost of emptying cesspits for ten private dwellings was roughly the same, around 5.60 guilders per pit. Emptying the cesspit at the orphanage itself, which served as a privy shared by about twenty children, was more expensive, at 13.80 guilders.

Patchy documentation concerning the cost of emptying cesspits exists for several European towns. In London, around AD 1400 , the price per ton of muck removed by a privy cleaner varied from $4 \mathrm{~s} / 8 \mathrm{~d}$ for small quantities to $3 \mathrm{~s} / 4 \mathrm{~d}$ for larger quantities (Sabine, 1934: 315-16). In Lüneburg, Germany, where in 1695 three to four nightmen needed twenty-one nights to empty the cesspit of the city tavern, they were paid 120 Reichstaler (Ring, 2004: 241). Such figures would be more meaningful when compared to contemporary monthly rental rates. From a small sample of rental homes from the period 16201635, we know that in Leiden the average monthly rent ranged from 5.50 guilders in 1627 to 6.60 guilders in 1635 , which would mean that emptying a cesspit would have cost roughly the equivalent of one month's rent (Posthumus, 1939: 1008-09). In Alkmaar, the average cost of emptying a cesspit in 1634 ranged from 6 to 10 guilders (Bitter, 2011: 43) while the average monthly rent in 1632 was 3.60 guilders (Van den Berg \& Van Zanden, 1993: 207). Here the cost of emptying a cesspit for a private dwelling would be the equivalent of 1.5-2.5 months' rent. In Haarlem the average cost of clearing out a cesspit in the years 16461658 was 5.60 guilders. According to the records for four of the houses used in the data collection, which also include the rent being paid for these houses, the cost of clearing the cesspit was exactly one month's rent for one house and 2.5 times the monthly rent for the other three (Van Oosten, 2015: appendix 3.2).
For Sara de Haen, an old and ailing widow who rented a dwelling for 2.35 guilders a month from Sint Agnietenhof, the bill to have her cesspit emptied would have been equivalent to double her monthly rent. We know this because the cost of emptying her cesspit was properly recorded by her institutional landlord, as emptying the cesspits in Sint Agnietenhof was part of their maintenance obligation. De Haen, who more than once had had to request suspension of debt repayment, could count herself lucky, along with other seventeenth-century tenants, because it was their landlords, both institutional and private, and not the tenants who bore the cost of emptying the cesspits (see Table 1 for the cost and frequency of emptying de Haen's cesspit.) The accounts of the almshouses in Leiden reveal that their cesspits needed to be emptied every other year. The frequency of cleaning the pits was probably somewhat lower in Haarlem as the historical records reveal that cesspits were emptied every six years (Van Oosten, 2015: appendix 3.2).

The trend is obvious: emptying cesspits cost the equivalent of one to three months' house rent and took place every few years. Given the cost and the obligation of master developers and landlords to attend to cesspits, it is obvious why they wanted to get rid of them. They made an attempt to kill off the cesspit in 1463 , but at that time local laws prohibited it. However, why the local government allowed it in 1583 still requires an explanation.

\section{Leiden: The Body Social EXPIREd by 1600}

Although Haarlem and Leiden went through similar processes of urbanisation, their sanitation policies differed. To explain why Leiden's local government allowed the master developers to kill off 
Table 1. Frequency and cost of emptying the cesspit of Sara de Haen, Rapenburg 48C, Leiden

\begin{tabular}{lcc}
\hline Date & Number of tubs & Cost in guilders-stuivers-pennies \\
\hline 20 September 1603 & 95 & $5-8-12$ \\
9 July 1605 & 72 & $4-10-0$ \\
8 December 1607 & 87 & $5-8-12$ \\
5 June 1608 & 100 & $6-5-0$ \\
23 November 1611 & 90 & $5-12-0$ \\
4 May 1613 & 110 & $6-17-8$ \\
\hline
\end{tabular}

Source: ELO, Sint Agnietenbegijnhof inv. no. 27A, Bijlagen bij de rekeningen. Thanks are due to P.J. M. de Baar (Leiden) who kindly provided this information.

the cesspit, we need to focus on Haarlem first.

Haarlem's policy on the construction of sewers differed from Leiden's. This is evident not only from the cesspit trend (Figure 4), but also from the fact that the city council continued to enforce strict and elaborate regulations regarding the emptying of cesspits (in 1658, 1706, 1708, and 1751). ${ }^{12}$ The city council repeatedly stressed that the direct drainage of waste water, even accidental spillage, into canals was prohibited. Historical records reveal that in Haarlem the brewers kept a sharp eye on the quality of the water in the canals from which they drew their water for brewing (NHA, Archief van het brouwersgilde, inv. no. 26, dated 1591, f. 4v.). The town council promulgated a by-law in 1549 stating that brewers would be fined if their beer tasted brackish, so they resorted, during some summers, to importing fresh water from the dunes (Huizinga, 1911: 281 [dated 21 May

\footnotetext{
${ }^{12} \mathrm{~KB}$, Ordonnantie secreetreinigers, Haarlem 1658. KW Plakk Q 264a, no. 19, Ordre ende reglement op de secreet-reynigers ende nachtwerckers, Haarlem, 29 January 1658; NHA, Ordonnantie secreetreinigers, Haarlem 1706, Renovatie en ampliatie van het reglement en de ordre op de secreet-reynigers en nachtwerckers; NHA, Ordonnantie secreten, Haarlem 1708, Renovatie en ampliatie van de keuren ende ordonnantien op 't subject van de secreten, Haerlem, 1708; NHA, Ordonnantie secreetreinigers, Haarlem 1751, Ordonnantie van de secreet-reynigers en nachtwerkers binnen de stad Haerlem, Haarlem, 13 January 1751.
}

1549] and p. 392 [no date]; NHA, Archief van het brouwersgilde, inv. no. 26, dated 1591, f. 4v). As of 1622 they drew water from the Oude Brouwerskolk (Old Brewers' Pool) located to the west of Haarlem (NHA, Archief van het brouwersgilde, inv. no. 119; Sliggers, 1987: 34; Unger, 2001: 166-67). Over the course of the sixteenth century, Haarlem's brewers wrote several letters to the city council in which they emphatically stated that brewing was the main industry of the town and that water pollution would harm the town's prosperity, and in which they asked explicitly that the establishment of contaminating industries be forbidden (NHA, Archief van het brouwersgilde, inv. no. 26). The Haarlem brewers were further involved in years of legal proceedings against bleachers who washed their cloth and drained their so-called stenchditches, polluted with buttermilk and soap suds, into the River Spaarne (Luyken, 1979: 49; Unger, 2001: 166; NHA, Archief van het brouwersgilde, inv. no. 86, dated 1583, NHA, beeldbank, inv. no. 51-000475). There is no conclusive historical evidence that Haarlem's brewers lobbied against the building of sewers, but with brewery being the primary industry and one that depended on a clean water supply, they would have taken a dim view of the watercourses being polluted with human excrement. 
Leiden too had breweries: in 1669 there were at least seventeen brewers (Van Dekken, 2010: 44, 47). It was not until 1658 , a hundred years after the by-law on brackish-tasting beer was passed in Haarlem, that the Leiden local authorities required brewers to draw lake water from the Valkenburgse Meer during the summer (Smit, 2001: 63; Van Dekken, 2010: 88-89). Adam Thomas Verduyn, presenting himself as 'a true friend of the common good ${ }^{13}$ (Verduyn, 1670b; 1), doubted that they abided by this regulation. In 1670 he published three small booklets in which he argued that Leiden's brewers were too stingy, and that Leiden's water quality was more compromized than Haarlem's. After describing seventeenthcentury Leiden's typical sewerage system, Verduyn states that the Leiden brewers did not hesitate to draw their water from the filthy canals. In his words: 'They serve people their own foul urine, mixed with faeces and water ${ }^{14}$ (Verduyn, 1670a: 13).

The quality of the water badly affected public health. A contemporary burgher by the name of Van der Goes noted in a letter dated 5 September 1669 that in Leiden an outbreak of a disease was caused by the reeking water and the beer brewed from it' ('ontstaen door het brack, stinckent water en bier daeruyt gebrouwen'; Gonnet, 1909: 81; also quoted by Buisman, 2000: 626). He reckoned that between 14 June and 12 December at least 1900 townspeople died and 40,000 fell ill on account of the beer and water (Gonnet, 1909: 92, letter dated 12 December 1669 and 81, letter dated 5 September 1669). Van der Goes dismissed as ridiculous the popular, local explanation that in general the culprit was the brackish water draining from Amsterdam, and the chairman of the

\footnotetext{
${ }^{13}$ 'liefhebber van het gemeene beste'

${ }_{14}$ geven zij den luyden haer vuyle pis, met dreck en water gemenght, te drincken'
}

dijkgraaf (water-management board), $\mathrm{Mr}$ Van Matenes, in particular (Gonnet, 1909: 123, letter dated 28 April 1670).

In those days the epidemic was simply referred to as 'the disease' or 'fevers'. ${ }^{15}$ In Leiden. De geschiedenis van een Hollandse stad published in 2003 Noordam suggests that the disease was malaria (2003: 48). This is quite possible as a Europe-wide malaria epidemic has been documented between 1678 and 1682 (Kohn, 2008: 118), and Leiden was also plagued with malaria in 1719 (Van Thiel, 1922: 5). The medical historian Pieter Hendrik van Thiel however doubts that the epidemic of 1669-1670 was malaria, as the course of the disease was atypical (Van Thiel, 1922: 5). Van der Goes may provide an important clue in one of his letters: he notes that the victims dying in February 1670 'developed a bluish rash'16 ('alle blaeuw gespickelt uytslaen'; Gonnet, 1909: 106, letter dated 6 February 1670), suggesting it may have been cholera, which was dubbed 'the blue death.' But it was not the type of cholera that swept through the country during the nineteenth century, cholera Asiatica, but probably the more common kind known as cholera nostrum.

Although the Leiden brewers were concerned about the quality of the water, albeit to a lesser extent than their fellow brewers in Haarlem, it was not they who were responsible for introducing sewers and killing off the cesspit. The trigger was pulled by the fourth group of stakeholders, the industrialists or more specifically the textile entrepreneurs. It was a convergence of financial interests linked to the textile industry.

The permission to build sewers in Leiden must be considered in the context of an extreme housing shortage. It is important to realize that the city fathers

\footnotetext{
${ }^{15 ،}$ coortsen'

16، alle blaeuw gespickelt uytslaen'
} 
regarded the influx of skilled workers from 1585 onwards as 'a divine blessing' (Lucassen \& De Vries, 1996: 138). The local government of Leiden, consisting mainly of textile entrepreneurs, were ready to welcome as many skilled textile workers from the southern Netherlands as possible. Leiden did not want them to go elsewhere, to Amsterdam or Haarlem (Posthumus, 1939: 159). Prior to the extension of the town boundaries in 1611, the town council of Leiden had repeatedly called for expanding the town; indeed they regretted that too few workers (arbeytsluyden) were settling locally, 'owing to a lack of appropriate housing' ('door gebreck van bequame huysinge; Van Oerle, 1975: 350). In the seventeenth century the top textile entrepreneurs constantly pressed for an expansion of the town to provide housing for their workers (Posthumus, 1939: 977). Eventually, obstructive regulations governing house construction were lifted, and contrary to mediaeval regulations, the building of timber dwellings was permitted (Daelemans, 1975: 200). The town council gave free rein to the housing industry to remedy the shortage as soon as possible.

By 1640 the shortage was still severe. So many inhabitants lived intra muros 'that no dwellings were unoccupied and there were no vacant areas where anyone might live properly' ('datter geen huysen off plaetsen ledich staen, waer yemandt bequamelick soude mogen wonen'; Posthumus, 1939: 976). Large dwellings were demolished to be replaced by 'small hovels' ('kleine krotties'; Posthumus, 1939: 977). The town council even took the exceptional measure of removing the builders' monopoly. It was no longer necessary for bricklayers, carpenters, and other craftsmen to be members of a guild to ply their trade. The town council assumed that foreign artisans and 'cobblers' would work with greater speed than guild members (Posthumus, 1939: 977-78).
The priorities of the town administration in Leiden had shifted fundamentally. Leiden had by definition become a pre-industrial capitalist textile town, which was reflected in policies that were governed by the dictum 'the more textile workers, the more looms, the more prosperity.' The end of the cesspit era, with sewage now draining directly into the canals, was an accomplished fact. This policy change can only be interpreted as material evidence of a fundamental shift in mentality, in which the common good had been abandoned and the needs of the few now outweighed the needs of the many. The earlier sanitation policies of the Middle Ages, flawed as they may have been, had been exchanged for the sanitation and hygienic conditions normally only associated with the nineteenthcentury Industrial Revolution, with all the negative consequences it entailed.

\section{Haarlem: The End of The Cesspit ERA}

Archaeological surveys in Haarlem have shown that the use of cesspits continued into the seventeenth and eighteenth centuries, although the number of cesspits per capita declined; in the course of the nineteenth century, cesspits were eventually replaced by sewers and canals reduced to open sewers. Just as Verduyn had done 200 years earlier in Leiden, Kruseman, a pharmacist, denounced the situation in Haarlem in 1859 , in a pamphlet on the deteriorating water quality in his hometown. The crux of his argument was to ask whether it is indisputably true that the cause of deterioration is the sewers that have been draining excrement into the canals since time immemorial ${ }^{17}$ (Kruseman, 1859: 4-5). Admittedly, fish no longer swam in the canals, but Kruseman supposed that this was primarily caused by 
industrial sewage, and he pointed the finger at the firm of Previnaire \& Co., a steam-powered cotton-printing and dyeing factory established along the Garenkokerskade on the north-western side of the old city centre (Kruseman, 1859: 9, 19). A scientific inquiry in 1859 however proved Kruseman wrong: it was not the sewage from the factories that fouled the water, but the high levels of human excrement (Van der Woud, 2010: 273, note 48). Kruseman was nevertheless correct in one regard. He had pointed out that immeasurable amounts of human excrement drain into the Oude Gracht (Old Canal) and Kraaijenhorstergracht (Crow's Nest Canal)' (Kruseman, 1859: 5). The open sewers of these two canals were the first canals to be filled in and turned into the Gedempte Oude Gracht (Filled-in Old Canal) and Nassaulaan Avenue respectively.

The shift from cesspits to sewers in Haarlem took place much like it had in seventeenth-century Leiden in that the stakeholders were the tenants, the landlords, the local government, and the textile industry (Figure 9). But, unlike in Leiden, the transformation took place not during an economic boom but during an economic downturn. Beginning in the eighteenth century, Haarlem's brewing industry saw a decline in its fortunes, caused by an increasing consumption of tea, coffee, and brandy; to make matters worse, the textile industry also declined. By 1800 Haarlem was definitely one of the impoverished towns of the Netherlands. For most of its residents it was a challenge to secure sufficient income to buy basic foodstuffs every week (De Vries, 1995: 341). Landlords are generally not known for taking good care of their

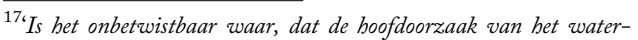
bederg te Haarlem gelegen is in de uitlozing der menigvuldige riolen in de stadsgrachten?'
}

properties; that landlords in the nineteenth century were dubbed 'lords of the slums' is most telling in this regard. If the slumlords refused to pay for clearing out the cesspits, then their often destitute tenants had little choice but to dump their waste into the water. It should however be noted that Haarlem's landlords, in contrast to those of seventeenth-century Leiden, were in no way 'rich capitalists, bleeding workers dry' (Van der Woud, 2010: 101). Landlords lived in the same neighbourhoods and were, at best, part of the middle class, trying to supplement their own modest income (Van der Woud, 2010: 100-03).

The local government did not have the capacity to check every infringement. Indeed it is debatable whether in the nineteenth century they even had the will to safeguard water quality. Rigorous enforcement with respect to private individuals would have been hypocritical, as the operators of the textile works were given free rein to pollute Haarlem's water on an industrial scale. It was clear that no obstructive regulations would be imposed on the textile industry. Initiatives by the local government to actively employ the growing number of impoverished townsfolk, such as inviting factories to set up shop in Haarlem, and the establishment of a 'municipal paupers' workshop' (Duba, 1985: 55) failed. A grant from the Nederlandsche Handelsmaatschappij (Netherlands' Commercial Company) however enticed two textile factories to begin production in Haarlem: the Phoenix Textile Works at the Ripperdapark, and Wilson's, which was established south of the old city centre (De Vries, 1995: 340-44). The textile printers Heeren Previnaire \& Co. had opened in Haarlem without a grant. These factories were expected to bring an end to the town's economic stagnation (De Vries, 1995: 34044), and Haarlem welcomed them. The local authorities were delighted that 


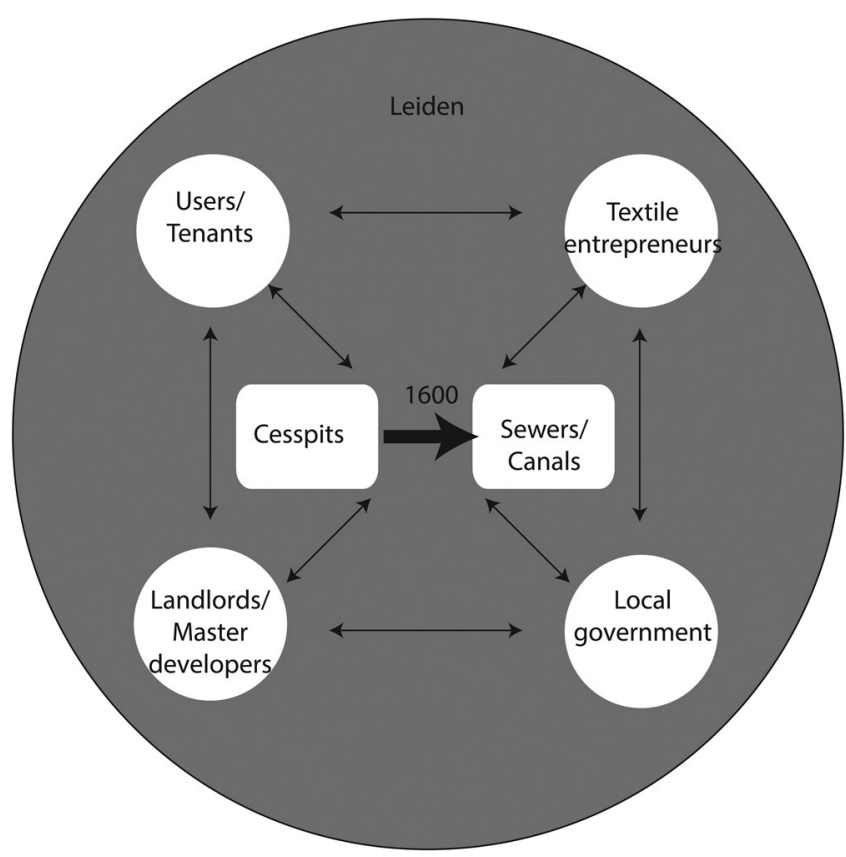

Figure 9. The shift from cesspits to brick-built sewers in c.1600 in Leiden represented in terms of the stakeholder model. The arrows indicate that all the stakeholder groups were interrelated and that all had a vested interest in the waste-management system.

Previnaire employed approximately 1000 textile workers: men, women, and even children (Verbong, 1987: 220; Verslag van den toestand der provincie Noord-Holland, 1861: $652)$.

This factory was renowned for its Turkish red textile (Verbong, 1987: 21921 ), and it was simply taken for granted by most people that Haarlem's canals were, at times, Turkish red. Hygienists, however, observed the effect on public health of draining industrial and human waste into canals and attempted to convince Haarlem's town council to improve the water quality, but to no avail; its economic interests were too great. Despite growing scientific evidence of the risk to public health posed by contaminated drinking water, local politicians obdurately dismissed the health risks. One councillor, who happened to be a textile baron himself, simply rejected the complaints of hygienists by claiming that 'the stench from the canals was not detrimental to health ${ }^{18}$ (Van der Woud, 2010: 188). Other manufacturers shared this view (Van der Woud, 2010: 188). Only after decades of foul, nauseating stench was the great stink of nineteenth-century Haarlem officially declared unbearable, almost at the same time as London. The open sewers, formerly canals, were rapidly filled in from 1860 onwards. 'Filling mania' swept through many other towns in the following decades. Eventually, albeit slowly, Haarlem returned to the 'greener' social policies of the seventeenth century. Together with Amsterdam, Haarlem was the first town in the Netherlands to establish a system of water mains.

\footnotetext{
${ }^{18 ،}$ de stank der grachten niet ongezond was'
} 


\section{Conclusion}

The end of the cesspit era in Leiden occurred around 1600; in Haarlem the cesspit era faded away as late as the nineteenth century when new textile companies moved in. Economic interests notwithstanding, the shift from cesspits to drains for the disposal of human excrement attests to shifting notions about the common good of the urban community. In sum, the demise of the cesspit demonstrates that the body social had expired. The transition from cesspits to a sewer system is tangible and material evidence of a shift in mentality.

In Leiden, the golden seventeenth century had a dark side: its great stink and deteriorating public hygiene. This phenomenon, in combination with Leiden's infamous grasping bakers, stingy brewers, and greedy textile entrepreneurs, was the result of focusing solely on increased production and meant that spinners, weavers, and tuckers in boom-town Leiden experienced an even grimmer and more insalubrious life than their counterparts in Haarlem. It would be interesting to see whether excavated skeletons or mortality rates bear out such local differences.

\section{ACKNowledgements}

I thank Xandra Bardet (Groningen) and Kerry Fast (Toronto) for helping me with the English text. I also thank Madeleine Hummler (York) and Laurent Verslype (Louvain) for the French abstract and Madeleine Hummler (York) and Natascha Mehler (Bremerhaven) for the German abstract.

\section{FuNDING}

The underlying research materials for this article can be accessed at Data Archiving and Networked Services (DANS) Doi:10.17026/dans-xaf-bqq4

(DANS

Easy-dataset 56516)

\section{ORCID}

Roos van Oosten (1) http://orcid.org/ 0000-0002-4323-5120

\section{REFERENCES}

Ampzing, Samuel. 1628. Beschrijvinge ende lof der stad Haerlem in Holland. Haerlem: Adriaen Rooman.

Annema, K.J. 1984. Ruimtelijke ontwikkeling tussen de Haarlemmer Houtstraten in een periode van honderd jaar. Een historischgeografische analyse van een stadssegment tussen 1543 en 1650. Unpublished MA dissertation, University of Amsterdam.

Bitter, P. 2011. Into the Pit? Waste Management and Cesspits Finds in Alkmaar. In: H. Clevis, ed. Assembled Articles 4. Symposium on Medieval and Post-Medieval Ceramics, Zwolle 16 and 17 September 2010. Zwolle: Stichting Promotie Archeologie, pp. 35-56.

Boeschoten, W.C. \& Van Manen, E. 1983. Een welstandsverdeling van Haarlem in 1543. Kwantitatieve toetsing van een zestiende-eeuwse fiscale bron. Bijdragen en Mededelingen betreffende de Geschiedenis der Nederlanden, 98(4): 523-39.

Brand, H. 2008. Een pre-industriële samenleving onder spanning. Leiden rond 1500. Leids Jaarboekje, 100: 95-120.

Buisman, J. 2000. Duizend jaar weer, wind, en water in de Lage Landen, vol. 4, 15751675. Franeker: Van Wijnen.

Daelemans, F. 1975. Leiden 1581: een sociodemografisch onderzoek. Afdeling Agrarische Geschiedenis Bijdragen, 19: 137215.

De Boer, D.E.H. 1983. Beerputten in Leiden, historische kanttekeningen ten aanzien van aanleg en verbreiding. Bodemonderzoek in Leiden Jaarverslag, 1982: 89-92.

De Boer, D.E.H. 1991. Leiden in de Middeleeuwen. In: J.K.S. Moes and B.M. A. de Vries, eds. Stof uit het Leidse Verleden. Zeven eeuwen textielnijverbeid. 
Leiden \& Utrecht: Dirk van Eck-Stichting \& Matrijs, pp. 33-46.

De Vries, B., Lucassen, J., Lourens, P. \& Nijboer, H. 2003. Het economische leven: spectaculair succes en diep verval. In: R.C. J. van Maanen, ed. Leiden. De geschiedenis van een Hollandse stad, 1574-1795, Vol. 2. Leiden: Stichting Geschiedschrijving Leiden, pp. 85-107.

De Vries, B.A.M. 1995. Dynamische ondernemers en onbeweeglijke standen. Economische ontwikkeling en sociale structuur. In: $T$. van Bueren, $S$. Groenveld, E.K. Grootes, J.M. Koomen-de Langen, J.J. Temminck and B.A.M. de Vries, eds. Deugd boven gerveld. Een geschiedenis van Haarlem, 1245-1995. Hilversum: Verloren, pp. 339-62.

Duba, W. 1985. Werkverschaffing in Haarlem 1771-1824. Haerlem Jaarboek, 1985: 48-64.

Evans, D.H. 2004. The Infrastructure of Hull between 1275 and 1700. In: M. Gläser, ed. Lübecker Kolloquium zur Stadtarchäologie im Hanseraum: Die Infrastruktur IV. Lübeck: Schmidt-Römhild, pp. 51-73.

Evans, D.H., 2010. A Good Riddance of Bad Rubbish? Scatological Musings on Rubbish Disposal and the Handling of 'Filth' in Medieval and Early Post-Medieval Towns. In: K. de Groote, D. Tys and M. Pieters, eds. Exchanging Medieval Material Culture. Studies on Archaeology and History Presented to Frans Verhaeghe. Relicta Monografieën 4. Archeologie, Monumenten- en Landschapsonderzoek in Vlaanderen. Brussels: Flemish Heritage Institute, pp. 267-78.

Gläser, M. 2004. Die Infrastrukturen der Stadt Lübeck im Mittelalter und in der frühen Neuzeit. In M. Gläser, ed. Lübecker Kolloquium zur Stadtarcbäologie im Hanseraum: Die Infrastruktur IV. Lübeck: Schmidt-Römhild, pp. 173-96.

Gonnet, C.J. 1909. Briefwisseling tusschen de gebroeders van der Goes (1659-1673). Vol. 2 , Werken uitgegeven door het Historisch Genootschap, Derde serie, nr. 11. Amsterdam: Müller.

Hamaker, H.G. 1873. De middeneeurwsche keurboeken van de stad. Leiden: Van Doesburgh.

Houwaart, E.S. 1991. De bygienisten. Artsen, staat en volksgezondheid in Nederland
1840-1890. Groningen: Historische uitgeverij.

Huizinga, J. 1911. Rechtsbronnen der stad Haarlem. Werken der Vereeniging tot uitgave der bronnen van het Oude Vaderlandsche Recht (WVOVR) Tweede reeks nr. 13. 's-Gravenhage: Nijhoff.

Jacobs, E. 2003. Spitten aan het Spaarne: een uitputtend verslag. Haarlems Bodemonderzoek, 36: 35-103.

Johnson, S. 2006. The Ghost Map: The Story of London's Most Terrifying Epidemic - And How it Changed Science, Cities and the Modern World. New York: Riverhead.

Jørgensen, D. 2006. Medieval Latrines and the Law. Medium Aevum Quotidianum, 53: 516.

Jørgensen, D. 2010a. 'All Good Rule of the Citee': Sanitation and Civic Government in England, 1400-1600. Journal of Urban History, 36(3): 300-15.

Jørgensen, D. 2010b. Local Government Responses to Urban River Pollution in Late Medieval England. Water History, 2: 35-52.

Kaptein, H. 1998. De Hollandse textielnijuerheid 1350-1600. Conjunctuur en continuïteit. Hilversum: Verloren.

Kohn, G.C. 2008. Encyclopedia of Plague and Pestilence: From Ancient Times to the Present, 3rd ed. New York: Infobase Publishing.

Kruseman, I.C. 1859. Het grachtwater binnen Haarlem: de voorgeslagen middelen tot verbetering kortelijk beschouwd in verband met de oorzaak van het bederf. Haarlem: Kruseman.

Latour, B. 1996. Aramis or the Love of Technology, trans. by C. Porter. Cambridge, MA: Harvard University Press.

Lesger, C. 1986. Huur en conjunctuur. De woningmarkt in Amsterdam, 1550-1850. Amsterdamse Historische reeks no. 10. Amsterdam: Historisch Seminarium van de Universiteit van Amsterdam.

Lucassen, J. 2002a. Holland, een open gewest. Immigratie en bevolkingsontwikkeling. In: T. de Nijs and E. Beukers, eds. Geschiedenis van Holland vol. II, 1572 tot 1795. Hilversum: Verloren, pp. 181-215.

Lucassen, J. 2002b. Immigranten in Holland 1600-1800. Een kwantitatieve benadering. Working Papers 3. Amsterdam: Internationaal Instituut voor Sociale Geschiedenis. 
Lucassen, L. \& De Vries, B. 1996. Leiden als middelpunt van een Westeuropees textielmigratiesysteem, 1586-1650. Tijdschrift voor Sociale Geschiedenis, 22(2): 138-67.

Lunsingh Scheurleer, T.H., Fock, C.W. \& Van Dissel, A.J. 1986-92. Het Rapenburg: geschiedenis van een Leidse gracht, Vol. 6. Leiden: Rijksuniversiteit Leiden.

Luyken, B.F.J. 1979. Haarlem en de verwerking van het huisvuil: een stukje milieuzorg van vroeger en nu. Haerlem Jaarboek, 1978: 47-76.

Meijer, H. 2005. Het vuil, de stad en de dokter. Onderzoek naar het functioneren van de Stadsgenees- en heelkundigen ten tijde van en in verband met de cholera-epidemieën in Leiden in de $19^{\text {de }}$ eeurw. Leiden: s.n.

Meijer, Y. \& Van den Bos, P.A. 2014. Archeologische begeleiding en opgraving. Nobellocatie Leiden, gemeente Leiden. IDDS Archeologie Rapport 1638. Noordwijk: Industrial Design and Development Services.

Noordam, D.J. 2003. Demografische ontwikkeling. In: R.C.J. van Maanen ed. Leiden. De geschiedenis van een Hollandse stad 1574-1795, Vol. 2. Leiden: Stichting Geschiedschrijving Leiden, pp. 43-53.

Noordam, D.J. n.d. De $10^{\mathrm{e}}$ penning Leiden 1561. Regionaal Archief Leiden, SAI, nr. 993. [accessed 10 November 2015]. Available at: www.janvanhout.nl.

Posthumus, N.W. 1908. De geschiedenis van de Leidsche lakenindustrie, Vol. $1 . \quad$ De Middeleeuwen (veertiende tot zestiende eeuw), 's-Gravenhage: Nijhoff.

Posthumus, N.W. 1910. Bronnen tot de geschiedenis van de Leidsche textielnijuerheid, eerste deel, 1333-1480. 's-Gravenhage: Nijhoff.

Posthumus, N.W. 1939. De geschiedenis van de Leidsche lakenindustrie, Vol. 2. De Nieuwe tijd (zeventiende en achttiende eeuw), 's-Gravenhage: Nijhoff.

Pot, G.P.M. 1994. Arm Leiden. Levensstandaard, bedeling en bedeelden, 1750-1854. Hollandse Studiën 31. Hilversum: Verloren.

Poulussen, P. 1987. Van burenlast tot milieubinder: het stedelijk leefmilieu, 1500-1800. Leefmilieu $\mathrm{Nu}$ 28. Kapellen: DNB/ Pelckmans.

Rawcliffe, C. 2013. Urban Bodies. Communal Health in the Late Medieval English Towns and Cities. Woodbridge: The Boydell Press.

Ring, E. 2004. Archäologische und schriftliche Quellen zur Infrastruktur der Stadt
Lüneburg im Mittelalter und der frühen Neuzeit. In: M. Gläser, ed. Lübecker Kolloquium zur Stadtarchäologie im Hanseraum: Die Infrastruktur IV. Lübeck: Schmidt-Römhild, pp. 237-47.

Sabine, E.L. 1934. Latrines and Cesspools of Mediaeval London. Speculum, 9(3): 303-21.

Sliggers, B.C. 1987. De loop van het Spaarne. De geschiedenis van een rivier. Haarlem: Schuyt \& Co.

Smit, C. 2001. Leiden met een luchtje. Straten, water, groen en afval in een Hollandse stad, 1200-2000. Leidse Historische Reeks nr. 15. Leiden: Primavera Pers.

Soly, H. 1977. Urbanisme en kapitalisme te Antwerpen in de 16de eeuw. De stedebouwkundige en industriële ondernemingen van Gilbert van Schoonbeke. Brussel: Gemeentekrediet van België.

Stein, R., Boele, A. \& Blockmans, W. 2010. Whose Community? The Origin and Development of the Concept of Bonum commune in Flanders, Brabant and Holland (Twelfth-Fifteenth Century). In: E. Lecuppre-Desjardin and A.-L. van Bruaene, eds. De bono communi. The Discourse and Practice of the Common Good in the European City $(13 t h-16 t h \quad$ c.). Turnhout: Brepols, pp. 171-204.

Taverne, E. 1978. In 't land van belofte in de nieue stadt. Ideaal en werkelijkheid van de stadsuitleg in de Republiek 1580-1680. Maarssen: Schwartz.

Unger, R.W. 2001. A History of Brewing in Holland, 900-1900: Economy, Technology and the State. Leiden: Brill.

Van Dekken, M. 2010. Brouwen, branden en bedienen: productie en verkoop van drank door vrouwen in de Noordelijke Nederlanden in de Nederlandse dranknijuerheid, circa 1500-1800. Zaandam/Amsterdam: Amsterdam University Press.

Van den Berg, W.J. \& Van Zanden, J.L. 1993. Vier eeuwen welstandsongelijkheid in Alkmaar, ca. 1530-1930. Tijdschrift voor Sociale Geschiedenis, 19 (2):193-215.

Van der Paauw, S. 1828. Verbaal van de Middelen tot verversching van het water in de grachten der stad Leyden, gedurende eene reeks van bijna tweehonderd en vijftig jaren. Leiden: L. Herdingh en Zoon.

Van der Woud, A. 2010. Koninkrijk vol sloppen. Achterbuurten en vuil in de negentiende eeuw. Amsterdam: Bert Bakker. 
Van Maanen, R. 2009. De Leidse bevolkingsaantallen in de $16^{\text {de }}$ en $17^{\text {de }}$ eeuw. Enkele kanttekeningen. Leids Jaarboekje, 101: 41-70.

Van Maanen, R. 2010. Jan van Hout, het Armenrapport en Vives. Jaarboek Dirck van Eck, 3: 21-35.

Van Oerle, H.A. 1975. Leiden binnen en buiten de stadsvesten. De geschiedenis van de stedebouwkundige ontwikkeling binnen het Leidse rechtsgebied tot aan het einde van de gouden eeuw, Vol. 2. Leiden: Brill.

Van Oosten, R.M.R. 2015. De stad, het vuil en de beerput. De opkomst, verbreiding en neergang van de beerput in stedelijke context. Leiden: Sidestone Press.

Van Thiel, P.H. 1922. Anopheles en malaria in Leiden en naaste omgeving. Dissertation Leiden University.

Van Zanden, J.L. 1991. Arbeid tijdens het handelskapitalisme. Opkomst en neergang van de Hollandse economie 1350-1850. Bergen, he Netherlands: Octavo (= J.L. Van Zanden 1993: The Rise and Fall of Holland's Economy. Merchant Capitalism and the Labour Market. Manchester: Manchester University Press).

Van Zanden, J.L. 1998. Did Holland's Golden Age Breed Inequality? In: L. Soltow and J.L. Van Zanden, eds. Income and Wealth Inequality in the Netherlands 16th-20th Century. Amsterdam: Het Spinhuis, pp. 23-54.

Van Zanden, J.L. n.d. Prices and Wages and the Cost of Living in the Western Part of the Netherlands, 1450-1800, Explanation of the Datafile "The Prices of the Most Important Consumer Goods, and Indices of Wages and the Cost of Living in the Western Part of the Netherlands, 1450 1800'. [Accessed 8 October 2015]. Available at: www.isg.nl.

Van Zon, H. 1986. Een zeer onfrisse geschiedenis. Studies over niet-industriele verontreiniging in Nederland, 1850-1920. Den Haag: Ministerie van Volkshuisvesting, Ruimtelijke Ordening en Milieubeheer.

Verbong, G. 1987. Coloristen en laboratoria, de ontwikkeling van het coloristisch werk in de Nederlandse textielveredelingsindustrie. In: R.P. Visser and C. Hakfoort, eds. Werkplaatsen van wetenschap en techniek: industriële en academische laboratoria in Nederland, 1860-1940. Tijdschrift voor de geschiedenis der geneeskunde, natuurwetenschappen, wiskunde en techniek, 9(4): 216-32.

Verduyn, A.T. 1670a. Water-krygh of een tweede missive, geschreven aen een particulier vriendt; over het sluyten van het water na de Haerlemmer-meren, het dammen van de Drecht en de Goutse Vaert. s.l.: s.n.

Verduyn, A.T. 1670b. Waterkryghs-praetje tusschen verscheyde persoonen; of derde missive aen een particulier vriend. Waer in wort aengewesen 't vervolgh vande waterkrijgh; en hoe dat Leyden en Amsterdam aen vers water konnen komen. Amsterdam: Jan Rieuwertsz.

Verslag van den toestand der provincie Noord-Holland, gedaan aan de Provinciale Staten van dat gewest door de Gedeputeerde Staten, 1861. Haarlem: Joh. Enschedé en zonen.

\section{Biographical Note}

Roos van Oosten has studied both Mediaeval History and Archaeology, and her $\mathrm{PhD}$ dissertation was an historicalarchaeological study of the 'cesspit era.' Since 2011, she has held the position of Assistant Professor of Urban and Mediaeval Archaeology in the Faculty of Archaeology, Leiden University. Her main research focus is on sanitation management and urbanization in the preindustrial period (1200-1800). A secondary focus is pre-industrial ceramic distribution patterns in relation to longterm economic trends. She is on the editorial board of Mediaeval and Modern Matters, a member of the advisory board of the Dutch classification system for Late-Mediaeval and Post-Mediaeval ceramics and glass, and chairperson of the Dutch Society for Mediaeval Archaeology.

Address: Leiden University, Faculty of Archaeology, Postbus 9514, 2300 RA Leiden, The Netherlands.

[email: r.m.r.van.oosten@arch.leidenuniv. $\mathrm{nl}]$ 


\section{La Grande Puanteur en Hollande: la fin des fosses d'aisances dans les villes préindustrielles de Leyde et Haarlem}

Au dix-neuvième siècle le déversement ininterrompu des effluents produits par des millions de Londoniens dans la Tamise, a produit d'insupportables et nauséabondes effluves estivales, dont la plus sévère fut immortalisée en 1858 sous le nom de "Grand Puanteur". Notre article a pour but de démontrer que, durant son rapide essor, les foules qui peuplaient la ville préindustrielle de Leyde ont également souffert les effets d'une "grande puanteur ". Celle-ci survint lors de l'abandon des anciens dispositifs de latrines et à la suite de leur remplacement par des égouts qui, désormais, se déversaient directement et à flux continu dans les canaux urbains. Malgré leurs défauts, ces fosses étaient plus salubres que la nouvelle infrastructure sanitaire prétendûment hygiénique qui a eut des conséquences aussi malsaines que celles que l'on attribue en général à l'ère de la révolution industrielle. Nous tenterons d'expliquer les causes et les modes d'éradication de ces fosses d'aisances en comparant Leyde à Haarlem, ville champignon du XVIIe siècle où les latrines survécurent à cet "âge d'or ". L'examen d'un modèle dans lequel toutes les parties prenantes de la collectivité urbaine sont prises en compte, démontre que les transformations de l'infrastructure sanitaire ne sont pas induites par une seule d'entre elles, par un seul intervenant déterminant. Ces transformations furent au contraire le résultat d'interactions plus complexes entre les promoteurs immobiliers, leurs locataires, les autorités municipales, les industriels du textile (à Leyde) et les brasseurs (à Haarlem). Translation by Madeleine Hummler and Laurent Verslype

Mots-clés: débuts de l'ère moderne, XVIIe siècle, Hollande, hygiène, infrastructure sanitaire, fosses d'aisances, modèle du multilatéralisme, "Grande Puanteur ", corps social, archéologie urbaine

\section{Der Große Gestank in Holland: das Ende der Klärgruben in den vorindustriellen Städten von Leiden und Haarlem}

Im neunzehnten Jabrhundert war die ununterbrochene Entsorgung der Fäkalien von Millionen von Londonern in die Themse verantwortlich für den bekannten, unerträglichen 'Großen Gestank', der jeden Sommer die Stadt überfiel und im Sommer 1858 einen kritischen Punkt erreichte. Im vorliegenden Artikel wird der Standpunkt vertreten, dass die aufstrebende und dicht bevölkerte vorindustrielle Stadt Leiden auch solch einen 'großen Gestank' erlitt, weil die Latrinen durch Abflussrohre ersetzt wurden, die direkt in die Kanäle entwässerten. Trotz ibrer Schwachpunkte waren die Latrinen hygienischer als die neue Abwasserinfrastruktur, die zu ungesunden Bedingungen - normalerweise erst im Zeitalter der industriellen Revolution bekannt - fübrte. Wie und warum die Latrinen abgeschafft wurden, wird durch einen Vergleich von Leiden mit Haarlem erklärt, eine florierende Stadt in der im 17. Jabrbundert die Latrinen dieses 'Goldene Zeitalter' überlebten. Die Anwendung des Mitbestimmungsmodells zeigt, dass die Abwasserinfrastruktur nicht von einer einzigen Interessengruppe verändert wurde, sondern durch die Wechselbeziehungen zwischen Bauunternehmer, Bewohner, Ortsbebörden, Textilunternehmer (in Leiden) und Brauer (in Haarlem) zustande kam. Translation by Madeleine Hummler and Natascha Mehler

Stichworte: frühe Neuzeit, 17. Jahrhundert, Holland, Entsorgung der Abwässer, hygienische Infrastruktur, Latrinen, Mitbestimmungsmodell, 'Großer Gestank', Gesellschaft, Stadtarchäologie 